\title{
SOIL NUTRIENT STATUS OF MOIST-DECIDUOUS FORESTS AT SIGIRIYA SANCTUARY, SRI LANKA ACROSS A CHRONOSEQUENCE OF FOREST AGE
}

\author{
E M S Ekanayaka, G A D Perera and G Seneviratne \\ Department of Botany, University of Peradeniya,
}

Soil nutrient status of moist-deciduous forests across a chronosequence of forest age was determined at Sigiriya sanctuary, Sri Lanka to determine the patterns of nutrient build up * with forest succession. Forty $20 \times 20 \mathrm{~m}$ experimental plots were established at different ages of sucessional forests grown after swidden farming and in mature forests older than 75 years. Two soil samples were collected from in each established experimental plots. Total carbon, nitrogen, phosphorus and mineralizable nitrogen, carbon, sodium, potassium, calcium, magnesium and clay contents were estimated.

Results revealed that the total nitrogen content increases with the process of succession despite the fact that fragmented soil litter results in exaggerating the total nitrogen contents. Fragmented soil litter accumulates in all forest due to high termite activity. Mineralizable nitrogen was found to be immobilized in the soil litter. Total carbon content of the soils of young successional forests increased with the increase of forest biomass and subsequent leaf litter accumulation with the process of succession. The high total carbon content in 10-15 year old forest soils is due to the incorporation of large amounts of litter after the self-thinning of plant individuals at about 6-7 years of age. However, it takes a longer time to build up the labile carbon contents within the soil. It seems that the clay content in the soil decreases with the increase of forest age, but it is actually due to the dilution of clay with organic matter. Both phosphorus and calcium contents in the soils of young successional forests were lower but higher in 20-25 years successional and mature forests despite the fact that these were somewhat high in 1 year old fallow forest. These fallow forests are the grazing grounds for domestic cattle and buffaloes and this may cause to add some nutrients in the soil. Potassium content in the soil is high in 10-15 years old forests and this may also be due to the incorporation of litter due to self-thinning of individuals.

It seems that swidden farming practices result into reducing the soil nutrients but after 10-15 years following swidden farming, the soil nutrient contents have increased at least started building up. Therefore, forest degradation inevitably takes place if the rotation period of swidden farming is less than 15 years. The soil nutrient contents in 20-25 years old successional forests are some what similar to mature forests implicating that these forests can be easily converted or rehabilitated into climax forests.

\section{Reference}

Anderson, J.M. and Ingram, J.S. 1993. Tropical Soil Biology and Fertility: a handbook of methods. Second edition, CABI Publishing, UK.

Proceedings of the Ninth Annual Forestry and Envinonment Symposium 2003 of the Department of Forestry and Environmental Science. University of Sri Jayewardenepura. Sri Lanka 